OPEN ACCESS

Citation: Bérengère Kolly (2021) Maria Montessori, pedagogical orthodoxy, and the question of correct practice (1921-1929). Rivista di Storia dell'Educazione 8(2): 49-58. doi: $10.36253 /$ rse- 10350

Received: January 24, 2021

Accepted: May 24, 2021

Published: December 16, 2021

Copyright: @ 2021 Bérengère Kolly. This is an open access, peer-reviewed article published by Firenze University Press (http://www.fupress.com/rse) and distributed under the terms of the Creative Commons Attribution License, which permits unrestricted use, distribution, and reproduction in any medium, provided the original author and source are credited.

Data Availability Statement: All relevant data are within the paper and its Supporting Information files.

Competing Interests: The Author(s) declare(s) no conflict of interest.

Editor: William Grandi, Università di Bologna; Rossella Raimondo, Università di Bologna.

\section{Maria Montessori, pedagogical orthodoxy, and the question of correct practice (1921-1929)}

\section{Maria Montessori, l'ortodossia pedagogica e la questione della pratica corretta (1921-1929)}

\author{
BÉRENGÈre Kolly \\ “Lettres, Idées, Savoirs" Laboratory, EA 4395, University of East ParisCréteil, Creteil, \\ France \\ E-mail: berengere.kolly@u-pec.fr
}

\begin{abstract}
The issue of correct practice (i.e., according to Henri Louis Go, practice that reflects the spirit and letter of a pedagogy), concerns every pedagogue, and Maria Montessori certainly took correct practice very seriously from the outset. Indeed, her emphasis on this crucial issue explains some of the strategic choices she made, as well as the ways she promoted her method abroad, and the relationships she maintained with her contemporaries (analyzed here via the early years of the journal Pour l'Ère nouvelle). These all led to accusations of dogmatism or pedagogical orthodoxy that continue to be leveled at the Montessori network today. This article sets out to explore the controversy surrounding the issue of correct practice in the field of pedagogy, taking Montessori as its example. Focusing on the 1920s, it considers the questions raised by attempts to protect a life's work within a heterogeneous array of philosophical and political practices and positions. It also explores the reticence that some of Montessori's contemporaries (particularly Decroly and Ferrière) showednot toward her pedagogy per se, but toward the way she conceived of and applied this pedagogy.
\end{abstract}

Keywords: Maria Montessori, New Education Fellowship, pedagogical orthodoxy, correct practice, internationalization of pedagogy.

\footnotetext{
Riassunto. La questione della pratica corretta (cioè la pratica che riflette lo spirito e la lettera di una pedagogia) riguarda ogni pedagogo, e Maria Montessori ha certamente preso molto sul serio la pratica corretta fin dall'inizio. Infatti, la sua enfasi su questa questione cruciale spiega alcune delle scelte strategiche che fece, così come i modi in cui promosse il suo metodo all'estero e i rapporti che mantenne con i suoi contemporanei (analizzati qui attraverso i primi anni della rivista Pour l'Ére nouvelle). Tutto ciò ha portato ad accuse di dogmatismo o di ortodossia pedagogica che continuano ancora oggi ad essere rivolte alla rete Montessori. Questo articolo si propone di esplorare la controversia che circonda la questione della pratica corretta nel campo della pedagogia, prendendo Montessori come esempio. Concentrandosi sugli anni '20, considera le questioni sollevate dai tentativi di proteggere il lavoro di una vita all'interno di una serie eterogenea di pratiche e posizioni filosofiche e politiche. Esplora anche la reticenza che alcuni dei contemporanei della Montessori (in particolare Decroly e Ferrière) mostrarono non verso la sua pedagogia in sé, ma verso il modo in cui concepì e applicò questa pedagogia.

Parole chiave: Maria Montessori, Nuova Educazione, ortodossia pedagogica, buone pratiche, internazionalizzazione della pedagogia.
} 
In memory of my brother, Quentin Kolly

\section{INTRODUCTION}

In 1914, Maria Montessori wrote in a letter to Augusto Osimo ${ }^{1}$, Director of the Humanitarian Society (Società Umanitaria), that the continuity of her pedagogy depended not only on the courses she gave, but also on at least one schooleven a small one "properly applying my method" ("col mio metodo ben applicato"), in order to lend value to my words "This is the fundamental thing, everything else can be remedied» («Ecco la cosa fondamentale, tutto il resto è rimediabile») (cited in Pironi 2018, 21).

The question of correct practice theorised in particular by Henri Louis Go (2007) theoretically concerns every pedagogue. In Montessori's case, it was a particularly pressing concern from the very outset, not least in Milan (Pironi 2007, 2018) ${ }^{2}$, and came through clearly in her relationships with other pedagogues (Kolly 2020). However, this key issue has yet to be explored as such by historians of education. We therefore set out to explore it in an original manner, for instead of studying Maria Montessori's writings, we decided to examine the views that her contemporaries expressed in the pages of Pour l'Ere nouvelle. The articles published in the early years of this journal clearly show that correct practice, or orthodoxy, was the aspect of Montessori's pedagogy that was most avidly discussed.

Maria Montessori explained on several occasions that while teachers were evidently free to make their own pedagogical choices, they had to be consistent once they had done so. Sheila Radice (1920) wrote in this regard:

If teachers want to get the same results that she has had, they will do as she has done; if they do not want to, they will not. One thing she objects to, and that is that teachers should make variations on her method and ascribe the results to her (Radice, 1920, 24).

It should be noted that this adherence to a single line of conduct and rejection of any mixing of pedago-

\footnotetext{
${ }^{1}$ Secretary, then Director of the Humanitarian Society in Milan, Augusto Osimo (?1923) worked closely with Maria Montessori (Pironi 2018), and was linked to Milanese socialist reformism. In addition to disseminating and providing training in the Montessori method, the Society promoted the principles of popular culture and education for the masses. Milan was at that time the center of the Montessori movement in Italy (Bucci 1990, 160).

${ }^{2}$ At the time when Montessori was starting to grapple with the question of how to disseminate her pedagogy while maintaining correct practice (Pironi 2018).
}

gies, interpreted as rigidity and dogmatism, has long beenand continues to bepresented as a key aspect of the Montessori movement (Kramer 1988, 377 et seq.; Pesci 2019, 105). We decided to take Montessori as an example of the controversy surrounding the question of correct practice in the field of pedagogy. We saw her as a generic case, enabling us to raise issues that are relevant to anyone who propounds a specific pedagogy. To this end, we looked at how Montessori's pedagogy was analyzed by her contemporaries in the early years of the journal Pour l'Ere nouvelle. These writers reproached Montessori less for her specific practices or philosophy than for the way she applied her pedagogy. The orthodoxyreal or imagined of Montessori's pedagogy was thus the main point under discussion. The term orthodoxy first appeared in 1924, in an article published in the journal by Ovide Decroly $(1924,63)$. At that time, it was used to designate educators who strictly applied Montessori's principles and techniques, without any additions or mixing; Decroly criticized Montessori's rigid attitude as hindering the widespread application of her pedagogy. The term was subsequently used many times in the journal to distinguish Montessorians strictu sensu from educators inspired by Montessori.

We attempt to show that this pedagogical controversy was far from merely anecdotal. First, the question of orthodoxy and correct practice influenced the strategies used to disseminate the Montessori method, the forms it took in other countries, and the degree to which it spread (just as it would for any pedagogy; see Droux and Hofstetter, 2015). Second, it explains some of the controversies and misunderstandings that arose between Montessori and several of her contemporaries, in particular Decroly and Adolphe Ferrière, who at that time were key figures in the field of new education (Depaepe, Simon and Gorp, 2003). It should be noted that we do not consider the New Education Fellowship to have been a coherent network, either practically or philosophically, owing to the considerable heterogeneity of its members' political and pedagogical positions. This is why we chose to explore this controversy via a single journal, the archives of Pour l'Ere nouvelle. First published in January 1922, this French-language journal affiliated with the International League for New Education (LIEN) reflected both new ideas in education and the diversity of the strategies adopted by members of the Fellowship. For each protagonist could potentially have a different relationship with and opinion about Montessori, and these could change over time ${ }^{3}$.

\footnotetext{
${ }^{3}$ Montessori had close relationships with several members of the Fellowship, including Elisabeth Rotten, who was Vice President of Association Montessori Internationale and subsequently became a psycho-
} 
This analysis highlights the reticence that some of Montessori's contemporaries displayed, not toward her pedagogy, but toward a certain way of conceiving of and applying it. By so doing, it provides an opportunity to think about the issues raised when attempts are made to protect a specific method (Montessori) within an array of philosophical and political practices and positions (New Education Fellowship). We chart the early years of Pour l'Ère nouvelle, from the conference in Calais (1921) to the one in Elsinore (1929). As a counterpoint, we also study the first issues of the Montessorian journal The Call of Education. In our chronological analysis, we describe I) the issues relating to dissemination and internationalization, II) the more pedagogical issues concerning the importance of the material versus the inventiveness of the teacher, and III) the more political issues involving the protection of a specific pedagogy or the affirmation of a plurality of pedagogies.

\section{MONTESSORI'S INITIAL INFLUENCE ON THE JOURNAL AND THE FIRST INCIDENTS (1921-1923)}

The Emergence of the New Education Fellowship: Shared Principles

From the very outset, LIEN had been based on a set of principles shared by pedagogues and educators. These six principles were 1) respect for the child's spiritual energy as the essential goal of education, 2) respect for the child's individuality, 3) respect for the child's innate and spontaneous interests, 4) the child' construction of his/her personal and collective discipline, as a first step toward social responsibility, 5) cooperation as opposed to competition, and 6) coeducation. An additional principle was the preparation, through education, of the future citizen, «but also the human being aware of his/ her human dignity» (International League for New Education 1922, 2).

These shared principles were supposed to allow for greater openness and flexibility, to take account of national or educational contexts. LIEN was thus seen as a movement, with no institutional basis or preordained direction, but with a resolutely European and international outlook (two other sister journals were published at the same time in German and English). Individual members and countries were free to «follow their own

analyst, André Berge, and even Ferrière. It is difficult to consider that this movement, which had no president and no institutional basis, had a unified way of thinking. We therefore propose a different analysis of the work by Catherine Lecuyer (2020), who carried out an analysis from Montessori's point of view. paths of development» (Ensor 1922, 7) ${ }^{4}$. In educational terms, the aim was to enable as many people as possible to take ownership of these common principles through personal initiatives and permanent renewal. The focus on principles was also intended to ensure wide dissemination, and to protect educators from "weariness" and "discouragement" by providing them with more technical resources. The premise of this ecumenical approach, which encouraged all those with good intentions, was that no particular pedagogy was to be favored.

The first few issues of Pour l'Ere nouvelle show a very clear Montessorian influence. However, in accordance with its principles, the journal laid claim to Montessori's ideas, but did not advocate applying her pedagogy to the letter. Thus, the third issue identified the dottoressa as just one of the movement's «four innovative trendsetters»: «Montessori in Italy, Decroly in Belgium, Cousinet in France, and New Schools throughout Europe» (ND 1922, 50). Nevertheless, the pedagogues who wrote about Montessori in the early issues presented themselves as either being inspired by her (Roger Cousinet, Maria Valli) or continuing her work (Maria Boschetti-Alberti, Virginia Povegliano Lorenzetto). This was a direct consequence of the principle of pedagogical syncretism whereby, according to Beatrice Ensor, «Every teacher should, as far as possible, study all the methods and draw inspiration from them to form his or her own» (Ensor, 1925, 4).

\section{The Incidents of 1923}

This syncretism inevitably clashed with Montessori's position. Whereas the educators writing in Pour l'Ère nouvelle shared principles that could be implemented in quite a heterogeneous way (horizontal extension), Montessori was concerned with the quality and protection of her specific practices (vertical deepening). In fact, the dottoressa had been moving in the opposite direction since 1907, as she had soon seen for herself what happened when her method was incorrectly or inaccurately applied. The practical difficulty of giving children freedom, but with guidance from the teacher, is a good example of this, and even today, these two practical points are particularly tricky to transmit and implement in Montessori practice ${ }^{5}$.

\footnotetext{
${ }^{4}$ All the archives of Pour l'Ére nouvelle are available online from the University of Caen: http://www.unicaen.fr/recherche/mrsh/pen Accessed: $28^{\text {th }}$ September 2021.

${ }^{5}$ Pironi points out that these difficulties were the subject of exchanges between Anna Maccheroni and Montessori as early as 1908: «difficulties encountered in trying to be a Montessorian teacher to the end, in trying to make the transition from 'disorder' to 'freedom', in trying to ensure that 'invitation' does not constitute an 'order» (Pironi 2018, 17).
} 
The essential and massive challenge for this groundbreaking pedagogue was to encourage the spread of her pedagogy without compromising correct practice.

The notion of correct practice was theorized by Henri Louis Go (2007) in relation to Célestin and Elise Freinet. It assumes that there is a correct way of practicing a given pedagogy (e.g., Montessori or Freinet) that affords access to the pedagogy's true meaning. To understand this, let us compare it with music: there is a right way for a performer to play a score, and a great performer is one who knows how to render the composer's intention and style in the most profound, refined and personal way possible. Adhering to great principles is therefore not enough: for each pedagogy, there are identifiable techniques, a style, but also a way of constructing the relationship with the child, even if there is always a personal and creative way of inhabiting this style ${ }^{6}$.

This explains the early publication of Il Metodo, as well as the speed with which Montessori started holding courses, intended to compensate for the lack of educators properly trained in the method. At this juncture, it is important to highlight another particular feature of Montessori's pedagogy, for although it relied from the outset on precise techniques and specific teaching materials, it also required an art of action that could not be reduced to a simple series of techniques.

Can these differences explain the two incidents that took place in the spring of 1923? The Montessorians certainly do not seem to have been keen to cooperate with the network of Pour l'Ere ouvelle. The first incident concerned the journal La Coltura Popolare, which was close to Montessori's ideas and network. In January, Pour l'Ére nouvelle announced that the two journals would henceforth collaborate, only to note somewhat regretfully in April that «the issues published thus far do not adhere to our rallying principles or give any indication of the goals we are pursuing, despite what seemed to have been agreed». The second incident involved Montessori herself. It had been announced in April that the pedagogue would be one of the speakers at the 1923 conference, only for her to cancel a few weeks before the event. Pour l'Ére nouvelle was indignant at this change in the program, and accused Montessori of "entrenchment" creation of a magazine specifically for Montessori added insult to injury.

\footnotetext{
${ }^{6}$ This concept is described in the following article: Kolly, and Go 2019.

7 This entrenchment was also blamed on William D. Owen, president of the National Educational Association, who likewise did not deign to reply to LIEN's letters. This was experienced as "a painful disillusionment", and described as an "exclusive reaction" (ND 1923, 22).
}

Mrs Montessori declares that she cannot go to Territet. It will be a great disappointment for many of us. (...) Mrs Montessori talks about creating a new journal. Why so many journals? Wouldn't it be better to reserve a few pages in each issue for Mrs Montessori and her collaborators? Or, if she prefers, every other issue, with more frequent publication? All things to be considered in due course. For this reason alone, her presence in Territet would be most desirable! (ND 1923, 44).

Pour l'Ére nouvelle does not seem to have received any specific explanation for these unexpected reversals, and deduced that they reflected a nationalist and pedagogical entrenchment that seemed totally at odds with the Fellowship's boast of eschewing partiality and partial exclusivism. Montessori's new commitment to children's religious education may also have been a factor, although it was not mentioned here. "We do not know your hatreds, we will say to them, whether these be nationalist, political or denominational» (ND 1923, 44). However, the second incident should, perhaps, be downplayed, as Pironi points out that Montessori was very busy abroad that year (in London from April to the end of July, and in the Netherlands from 27 August to 1 September ${ }^{8}$ ), and sometimes even failed to turn up at her own courses (e.g., course held in Milan in 1914; Pironi $2018,22)$. She also obviously gave priority to her existing commitments. Already internationally known, she may not have been interested in a small, mainly Frenchspeaking network with a still limited audience, and which quickly found itself in financial difficulty.

Two Divergent Strategies, Two Versions of Internationalism: The Call of Education

Nevertheless, Montessori clearly had a different strategy, as indicated in the summaries of the first three issues of The Call of Education, published from 1924 onwards. The aim of this Montessori journal was to examine issues linked not to general principles, but to a specific pedagogy, in order to help "the people who follow, serve and observe the souls of the children set free by our method of education"9. The journal contained scientific articles and texts on child psychology, as well as "replies to questions on the Montessori method", "practical help to teachers", "reflections on the results of the pedagogy", and writings on "social problems in the light

\footnotetext{
${ }^{8}$ I would like to thank Joke Verheul, archivist of Association Montessori Internationale, for this information, although there is no trace of this symposium on children's religious education.

${ }^{9}$ Montessori, Maria. 1924. "La chiamata / The call / Lappel". The Call of Education, 1-1, 3-17. Archives of Association Montessori Internationale, Amsterdam.
} 
of the method". The aim was obviously to "organize the countless forces scattered throughout the world, namely the forces of the apostles of our idea", as well as to "help the teachers who, without sufficient preparation, run Montessori schools". In fact, the Montessorian network, which had been in existence for more than 15 years (i.e., since 1907), and which was present in a number of countries, was seeking to structure itself via a specific publication, in a way that would not have been possible using an existing journalespecially given the allegiance that this would have entailed.

Thus, the internationalism envisaged by Montessori was backed up by her work. The Call of Education aimed to forge links across nations and cultures on the basis of common pedagogical practices. This involved bringing together specialists and educationalists, who exchanged equally in four languages (English, French, German, and Italian). The national correspondents were selected for their knowledge of the method, while the articles published by authors such as Géza Révéz, J.C.L. Godefroy, C.A. Claremont, Anna Maccheroni, and Montessori herself in the first issue were also explicitly linked to the Montessori method. Titles in this first issue included "Why is the Montessori Method a Science?" and "Questions Relating to the Development of Social Life in the Montessori School", while those in the second issue included "Child Character", "Sensitive Periods", and "Children's House in Berlin". By contrast, Pour L'Ėre nouvelle sought to link nations and cultures on the basis of broad general principles translated into multiple practices, all rooted in their national context. This choice led to the creation of several journals, each published in a specific language (English, German, and French), bringing together representatives of various practices, possibly mixed together, under a common theoretical banner. Thus, the former was intended to be a community, while the latter remained a movement.

This divergence explains subsequent discussions about orthodoxy, the formation of educational networks, and political commitment to or disengagement from pedagogy. For educators writing in Pour l'Ère nouvelle, there needed to be a common, internationally shared pedagogical policy, but possibly with differentiated, country-specific pedagogical approaches. For the Montessori network, there had to be a common pedagogical approach, but political approaches could differ. For the former, teaching practices were debatable and variable, and could be mixed because they were all affiliated to the same main principles. For the latter, pedagogical practices were not debatable, as they had to be philosophically and practically coherent. Their application in divergent political contexts was a secondary issue. This was a considerable strength, when it came to adapting to diverse cultural contexts, and therefore to ensuring universality, but also a political weakness, as the pedagogy has little intrinsic resistance to political context, for example.

\section{MONTESSORIAN ORTHODOXY CALLED INTO QUESTION (19241927)}

Unsurprisingly, Montessori was not invited to the next conference, and at its opening, Ferrière attacked the supposed permissiveness of the Montessori method (Ferrière 1923, 76). It should not, however, be inferred that Montessori's initial influence over the journal now waned. Rather, Pour l'Ère nouvelle adopted the singular approach of encouraging Montessori principles, but independently of the dottoressa and her network. The journal was therefore neither Montessorian nor antiMontessorian. Instead, it promoted a specific relationship with Montessorianism, which can only be understood through the difficult question of orthodoxy.

\section{The debate on orthodoxy (19241926)}

In October 1924, Decroly reviewed the Dutch experiment with new education that had begun in 1918 . He recalled that a Society for the Study of the Child had been created before World War I by Henriëtte Van Reesema-de Graaf in The Hague. Although this society had been dissolved after the war, it was the starting point for the Montessorian movement in Holland, complete with Montessori courses and Montessori schools, under the aegis of Cornelia Philippi-Van Reesema.

Decroly, whose trajectory had so far been similar to that of Montessori (work with the developmentally delayed, design of educational material, educational games, importance of freedom in work, and system of self-education), stated that he was «not enthusiastic about Montessori's materials», but «fully agreed with many of her principles, especially that of free work" (Decroly 1924, 17). The discussion about orthodoxy therefore began with the question of the materials, techniques, and pedagogical standards, and how far adults were supposed to adhere to them.

This debate about orthodoxy was closely linked to the fact that, for the pedagogues of Pour l'Ere nouvelle, the new education was essentially a sharing of principles. The nature of the techniques derived from these few principles was therefore left to the discretion of the teachers. Preferring certain techniques to others was necessarily viewed as a rigid attitude. 
Decroly began by saying that the Dutch experience had quickly ran out of steam, despite two visits by Montessori in 1921 and 1922, as the local teams felt that the children had made insufficient progress, and discipline was too difficult to establish. Decroly interpreted the problem in technical terms, deeming that the technique (i.e., material) was not suitable (too rigid, not diversified enough) for the children. This inadequacy generated boredom, such that the children could neither make progress nor take advantage of their freedom. Eschewing the hypothesis that the pedagogy had been poorly implemented, he described Holland as being divided into two camps: the camp of the orthodox, who «followed Mrs Montessori in everything», and the camp of the educators, who "followed the results of a serious experiment and wanted to have freedom of action", choosing to adapt the pedagogy by restricting children' initial freedom and extending the material in the form of games and facilities (Decroly 1924, 62).

Decroly's criticism is all the more interesting as Montessori had already been confronted with this type of argument back in 1912. That year, she had had an argument with Pierre Bovet, Director of the nascent Jean-Jacques Rousseau Institute, about a course on her pedagogy. Bovet had hired a former colleague of hers, Teresina Bontempi, to give the course, without consulting her first. This had angered Montessori, who refused to lend her name to a course that was not given by her, and which was purely practical. She withheld permission for a second edition of the course translation, and ceased all cooperation with Bovet, and therefore also with the entire Geneva network that had been behind the New Education Fellowship ${ }^{10}$. The correspondence between the two protagonists shows that, from Montessori's point of view, it was a question not of refusing all contact with the network ${ }^{11}$, but of refusing to allow the promotion of inaccurate practices (Bontempi's performance during a course held in Milan a few months earlier had swiftly been disavowed by the dottoressa; Pozzi 2015). However, misunderstanding was the order of the day, and Bovet duly interpreted the pedagogue's reaction as one of rigidity ${ }^{12}$.

Over the following years, orthodoxy became the main point of discussion concerning the Montessori method in Pour l'Ére nouvelle, as illustrated by three articles published by Philippi-Van Reesema in 1926. These

\footnotetext{
${ }^{10}$ For a detailed description of this controversy, see Kolly 2020.

${ }^{11}$ Maria Montessori wrote to Bovet that she was happy to be connected with the Jean-Jacques Rousseau Institute. Archives Institut Jean-Jacques Rousseau (AIJJR), Fonds général, FG.F.6/28: letter from Maria Montessori to Pierre Bovet, 21 October 1912.

${ }^{12}$ Letter from Pierre Bovet to Maria Montessori, 27 October 1913, Archives of Association Montessori Internationale, Amsterdam.
}

set out similar arguments: too much freedom given to children («causing [...] disillusionment among the headmistresses, as well as disorder and laziness among the children» (Philippi-Van Reesema 1926, 82), orthodoxy of practice, and reduction of the pedagogy to a form of training, owing to the practical failure of the material. The author added that as Montessori refused to acknowledge that her materials were not sufficiently diversified and adapted, she mistakenly assumed that her method was being incorrectly applied, and thus became inflexible ( Accuracy in the use of the materials was from then on laid down in principle; that is to say, it was no longer permitted to use the material other than in a strictly defined way»). Pedagogy is so reduced to a «systematic training of faculties and functions» Philippi-Van Reesema 1926, 174). Thus, it was neither the techniques nor the spirit of pedagogy that were at issue in this last article, but rather the orthodox way of applying the pedagogy.

The same arguments were rehearsed in articles written in the same period by Giuseppe Lombardo-Radice. He denounced «the narrowness and mechanical nature of the "Method", revolving around a fixed and rigid pivot, superstitiously regarded as... thaumaturgic», and contrasted it with the method developed by the Agazzi sis$\operatorname{ters}^{13}$. Lombardo-Radice further asserted that true orthodoxy was not where Montessori thought it was, and that Angela Santoliquido (who had taken over the first Children's House) was far more "faithful to the original Montessori method" (Lombardo-Radice, 1926, 176 and 181).

It should be noted that these arguments were all strictly technical, in that they reduced the Montessori method to a series of techniques. This was consistent with the notion of shared general principles, whereby techniques are disconnected from any ethos or praxis, and can thus be freely transmitted or adapted. It further implied that educators should be free to use (or not to use) the techniques. The question of correct practice (i.e., congruent with the spirit and letter of a specific pedagogy) was therefore absent from the discussion ${ }^{14}$.

\section{THE ETHICS OF THE EDUCATOR}

Touching briefly on ethics, from Montessori's point of view, the choice of orthodoxy, articulated with that of

\footnotetext{
${ }^{13}$ Ferrière agreed, stating in 1928 that the Agazzi method was "more specifically Italian, more lively and broader than Mrs Montessori's" (Ferrière 1928,8283 ).

${ }^{14}$ There is only one exception in the sources examined here: in January 1926, an article protested against "a few neo-artisans of the global method" using a "caricature of the Decroly reading games", "a mismatch between the old method of normal words and the ideo-visual method" (E.D. 1926, 810).
} 
correct practice, was an objective means of transforming the adult educator, who had a "delicate" task and whose action was a "great art" (Montessori 1913). For Montessori's contemporaries, the orthodox application of a pedagogy could be understood as a form of authoritarianism. However, we can see that this was an ethical misunderstanding of the place of the adult and his/her ethical role.

In the 1920s, Maria Montessori was still working out the place of the adult. According to her conception, described here on the basis of her later theorizing, the technicist vision of pedagogy had to be refuted. Techniques (including teaching materials) were to be thought of not as mere tools, but as levers for transformingand reformingeducators. Thus, «the teacher's training also included a "personal art", or individual refinement on the measure in the intervention» (Trabalzini 2011, 61).

This transformation involved first and foremost accepting that the educator was no longer at the center of the pedagogical activity, the idea being that the adult had to bend to the materials, as the latter were there to serve the child. This presupposed an initial acceptance of the pedagogy as a whole, with inventiveness or criticism only permitted in a second stage, which is when many of Montessori's collaborators created new techniques and gradually added to the initial materials. Therefore, orthodoxy was not so much aimed at the children as at the adults, insofar as the correct use of the material was part of their training and transformation. This explains why Montessori focused on controlling the training in her pedagogy, rather than on the pedagogy itself ${ }^{15}$. It was a question of preserving not only techniques, but also a pedagogical spirit, based on a reform of the adult that the training was supposed to trigger, and which no single method or technique could bring about.

This choice contrasted with that of the pedagogues who then occupied dominant positions in Pour l'Ëre nouvelle at that time. Decroly did not call for his method to be used correctly, and the question of his pedagogical legacy only arose after his death (see Wagnon 2013). Ferrière did not initiate any specific pedagogy. For both of them, it was only logical for techniques to be adapted to each audience, child, and situation, in a possible mix of pedagogies. Moreover, it was important to be able to adapt to the official curricula and various government injunctions ("the usual school framework", as Decroly put it) (Decroly 1924, 63), to which practitioners in public systems were subject. As Montessori focused on pre-

\footnotetext{
${ }^{15}$ In 1913, Montessori was already preoccupied with this question. She wrote in a letter to Bovet that she wanted to create a specific course, in order to "defend, explain and present" the principles of her pedagogy. AIJJR/FG.F.6/28: letter from Maria Montessori to Pierre Bovet, 31 October 1913 .
}

schooling, she did not need to engage in this kind of reflection, at least not initially.

Here we find the two contrasting strategies described earlier: inserting the same techniques and same, constant ethical base into diverse cultures and contexts (Montessori) versus teachers technically adapting the same principles to the various injunctions and curricula (Decroly, Ferrière). Ferrière wrote in 1925 that «the method of the Active School is singular in its scientific origin and principles, and plural in its formsthe form of each particular pedagogy being considered only "partial"» (Ferrière 1925, 21). According to this point of view, teachers were the drivers of pedagogical inventiveness, choosing their own techniques, creating their own tools, and adapting them to their audience.

\section{Construction of Pedagogical Movements}

These choices dictated the construction of pedagogical movements. The New Education Fellowship presented itself as a bottom-up movement made up of inventive educators, as opposed to a top-down pedagogy where educators endorse a pre-existing tradition. Decroly directly criticized the "orthodoxy of the inspirer", claiming that it generated overly subservient educators. For him, there was only a short step from pedagogy to movement, and from movement to politics, insofar as this posture was associated with dogmatism and a disconnection from practical life and from the people:

The orthodoxy of the inspirer has already created dissent, and we seek through reasonable eclecticism not to be hindered by dogmas that are too rigid and which do not correspond to real life or to the shifting and diverse nature of children's mentality. As always, commonsense people regret the excessive interference of purely mystical conceptions in practical life (Decroly 1924, 64).

The argument therefore gained a political dimension, moving from a crucial issue for practitioners (reform of the adult) to the difficult question of freedom, and whether or not the educator should intervene, giving the children work to do and attempting to trigger interest in an activity. The accusation that would be leveled at Montessori in the 1930s, whereby she confined herself to the position of pedagogue, neglecting issues of social transformation and the struggle against political authoritarianism, was already taking shape. The image of an elitist, private pedagogy, cut off from the people and their concerns, but also of a dirigist and even dictatorial pedagogy, contrasting with the plural and adaptable new education methods, was not far off. 


\section{FROM SILENCE TO CONDITIONAL OVERTURE (1926-1929)}

Before that, however, there was an upturn. In 1926, Ferrière went to Italy and visited Montessori. By his own admission, this encounter led him to reconsider his opinion of the pedagogue and her alleged views. As a result, Pour l'Ėre nouvelle finally published an article by Montessori in June 1927 (lecture given in September and October 1926 in Buenos Aires and first published in La Coltura Popolare), as well as an article explicitly positioning itself in favor of her pedagogy. This was the beginning of a more harmonious period, culminating in the cooperation around the 1929 Elsinore conference, the first one that Montessori personally attended. However, although there were fewer references to orthodoxy, LIEN's position did not change, and this new overture to Montessori remained a limited one.

\section{Ferrière's Mea Culpa: Recognition, but Only Under Certain Conditions}

Issue 23 of Pour l'Ere nouvelle carried a report of Ferrière's trip to Italy. It was an opportunity for the pedagogue to suggest that Montessori's silence, which contrasted with her tremendous celebrity, led to misunderstandings about her method and her conception of children.

Few women are as famous as Maria Montessori. But few people have come into contact with her. She does not attend conferences. She likes to listen, she says, but not to talk. She is averse to discussion (Ferrière 1926, 151).

Ferrière said he was assured that the dottoressa "appreciated" the work of the Rousseau Institute, Alice Descoeudre, and Jean Piaget. He also noted that she «has faith in the internal balance of the child, but only on condition that the class constitutes a collective mentality». He deduced from this that the public's conception of her pedagogy was often erroneous, and described how an encounter had enabled him «to understand in an infinitely more penetrating way her intimate thought and her eminently constructive spirit».

For this reason, he applauded the official recognition of her pedagogy by the Ministry of Public Education (under Mussolini, therefore ${ }^{16}$ ): «official recognition, after a period of ignorance that has lasted too long». Nevertheless, he specified that the dottoressa would gain from more contact with others when it comes to improving her method:

\footnotetext{
${ }^{16}$ For this question, see in particular Marazzi 2000.
}

There are many legends about Mrs Montessori's opinions. I have found in her a spirit that is willing to acknowledge science as the supreme arbiter: observation of the child and experimentation. But I believe that when she turns her attention to different types of children, she will make discoveries in this area that may well transform and enrich the effectiveness of her material (Ferrière 1926, 23, 152).

\section{Still Limited Discussion: The Locarno Conference}

However, this opening remained conditional. Correct practice was still an issue. Although Pour l'Ère nouvelle published an article by Montessori in 1927, as well as one by a colleague of hers in Holland who was opposed to Philippi-Van Reesema, these articles were both just reprints. Nevertheless, they were the first contributions from the orthodox camp. Catherina Ligt Van Rossem wrote about the use of the materials, speaking for «a Dutch association that is committed to [the method's] orthodox application, out of the justifiable fear that the dilettantism of amateur parents may rob it of its essential characteristics». While acknowledging "difficulties" in the application of this method, the author stated that there was a «duty to ensure that the essence of the new education remains intact» (Ligt Van Rossem 1927, 113115). Unfortunately, no real discussion ensued. Following these two articles, the editors chose to present the list of articles published by the journal on Montessorianism from the point of view of nonorthodoxy, not least "the very thorough study by Mrs Philippi-Van Reesema". This was a reaffirmation of the journal's position of unorthodox Montessorianism.

Another noteworthy fact is that although Montessori did not attend the Locarno conference in person, she did send Lili Roubiczek from Vienna. The latter attracted a group of Montessori supportersmuch to her surprise. Unsurprisingly, the paper she gave returned to the accusation of dogmatism. Roubiczek pointed out that the teaching materials remained of secondary importance, compared with the spirit of the pedagogy. She nevertheless pointed out that "Any well-prepared teacher who introduces these materials into her class will find them suitable for the children and corresponding in every detail to their intimate needs» (Roubiczek 1927, 229).

Once again, Pour l'Ere nouvelle counterbalanced this strict Montessorian viewpoint by publishing an article three times longer by Philippi-Van Reesema. This article questioned «the former psychology that sought to develop faculties by means of fixed materials» (PhilippiVan Reesema, Cornelia 1927, 230), defending instead the psychology of globality (thus favoring Decroly) and the importance of adapting to children's spontaneous activ- 
ity. Here, Philippi-Van Reesema accurately represented the position of the French-speaking network, confirmed by the report on self-educational material presented at the conference (which gave pride of place to Decroly's material and that of the Montessori-inspired Children's House) as «attempts (...) by which we aim to respond even better to children's spontaneous interests in the exercises we give do, and to stimulate them to freely engage in research and experimentation» (ND. 1927, 262-268).

These two examples show that the recognition of Montessori's pedagogy in 1927 remained conditional. Starting from the premise that this method could not suffice on its own, the question of orthodoxy could only lead to misunderstandings. Ferrière thus regretted that the work of Santoliquido, Director of the first Children's House, went unrecognized by the dottoressa, «just like all the efforts that deviate, however little, from her strict method» (Ferrière 1926, 152).

No other pedagogy was subject to this type of argumentdoubtless because Montessori was the only one who thought that her work would outlive her. We could, of course, hypothesize that Montessori was indeed authoritarian and dogmatic, and that she could not bear to see a pedagogy that only functioned poorly in the real world being called into question, especially since the reform of the adult, which would later become the focus of her pedagogy, was not fully theorized at the time. However, we could also argue that these misunderstandings were linked to the question of correct practice. In principle, according to this conception, a method can only ever be a single milestone along the way, meaning that the Montessori method could only be valid if it was then "perfected and complemented", as Ferrière wrote in 1926.

The journal issues that followed the report on the Locarno conference confirmed that attention had shifted away from the question of orthodoxy, and therefore away too from discussion of the Montessori method. Issues 34 and 35 contained two articles on "a Montessori class in Paris", describing in detail the application of the method in a public nursery class and advocating the "generalization of the application of the Montessori method in classes for young children" (Jotte 1928, 35). However, this new tolerance toward the Montessori method went hand in hand with its trivialization. It was discussed less often and was given a lower profile, not least in 1928 and 1929, when the Agazzi method received greater attention. Was it this loss of influence that led the pedagogue to attend the New Education Fellowship in Elsinore? This new openness on her part further manifested itself in Elisabeth Rotten's admission to Association Montessori Internationale (1937). However, a fresh controversy was already starting to emerge in the 1930s, over children's overwork, when Montessori would once again be taken to task.

\section{CONCLUSION: DO CRITICISMS OF ORTHODOXY MISS THE POINT?}

This article shows first and foremost that discussions of Montessori's pedagogy in Pour l'Ere nouvelle in the 1920s revolved almost exclusively around its real or supposed orthodoxy, without any discussion of the underlying issues, namely correct practice and the place of the educator. While returning to this important pedagogical controversy, the aim here was to restore a form of dialogue between the two parties involved, highlighting not only pedagogical differences, but also differences in dissemination strategies and conceptions of internationalism.

This article also tends to show that Montessori existed solely in controversial mode in the pedagogical field. This can easily be explained, for by operating as a community rather than a movement, her network chose to go deeper, not wider. Controversy and discussion therefore became necessary to extend its reach beyond its followers. In Pour l'Ere nouvelle, Montessori's pedagogy was synonymous with debate and criticism. Once the controversy had worn off, it became trivialized and its influence waned from 1926 onwards, only to return in force in the 1930s, with discussions about politics, religious education, and children's overwork.

This is intended to be a generic, textbook case. During her lifetime, Montessori encountered problems that can beset any groundbreaking pedagogy, not least when its founder grows old or dies. Orthodoxy is not the central issue, for it is not so much a question of knowing whether a pedagogy is rigid or dogmatic, as identifying the conditions in which a pedagogue can pass on his or her legacy.

\section{BIBLIOGRAPHY}

Baumann, Harold. 2007. Hundert Jahre Montessori-Pädagogik, 1907-2007. Eine Chronik der Montessori-Pädagogik in der Schweiz. Berne: Haupt.

Bucci, Sante. 1990. Educazione dellinfanzia e pedagogia scientifica. Da Froebel a Montessori. Rome: Bulzoni.

Decroly, Ovide. 1924. "Expériences d'éducation nouvelle à La Haye". Pour l'Ėre nouvelle, 12, 62-64

Decroly, Ovide. 1924. "La semaine de Villebon, compte-rendu, VII, De l'enseignement individuel dans les classes nombreuses". Pour l'Ére nouvelle, 13, $2-20$. 
E.D. 1926. "Chronique française". Pour l'Ère nouvelle, 18, 8-10.

Ensor, Beatrice. 1922. "Le Congrès de Calais". Pour l'Ère nouvelle, 1, 5-7.

Ensor, Beatrice. 1925. "Les fondements de l'éducation nouvelle". Pour l'Ere nouvelle, 17, 3-4.

Ferrière, Adolphe. 1923. "Discours d'inauguration du Congrès de Montreux". Pour l'Ére nouvelle, 8, 73-79.

Ferrière, Adolphe. 1925. "Nouvelles diverses". Pour l'Ère nouvelle, 14, 19-22.

Ferrière, Adolphe. 1926. "Une visite aux Pionniers de l'École Active en Italie”. Pour l'Ėre nouvelle, 23, 151-152

Ferrière, Adolphe. 1928. "L'école enfantine de Mme Agazzi, à Mompiano". Pour l'Ére nouvelle, 37, 82-83.

Go, Henri Louis. 2007. Freinet à Vence: Vers une reconstruction de la forme scolaire. Rennes: Presses Universitaires de Rennes.

Jotte, Alice. 1928. "Une classe Montessori à Paris". Pour l'Ère nouvelle, 35, 32-35.

Kolly, Bérengère, Go, Henri Louis. 2019. "Ecoles Montessori et Freinet, évitons les malentendus". The Conversation France, 22. https://theconversation.com/ debat-ecoles-montessori-et-freinet-evitons-les-malentendus-116844_Accessed : 28 September 2021.

Kolly, Bérengère, Go, Henri Louis. 2020. Maria Montessori et Célestin Freinet: voies et voix pour notre école. Paris: ESF.

Kolly, Bérengère. 2017, September. "Regards genevois sur Montessori et l'essaimage du Montessorisme". In Genève, une plateforme de linternationalisme éducatif au XXe siècle. Symposium conducted at the JeanJacques Rousseau Institute, Geneva, Switzerland.

Kolly, Bérengère. 2020. "Linternationalisation montessorienne selon la stratégie du double gain: diffraction et problématiques de diffusion." In Construire la paix par l'éducation: réseaux et mouvements internationaux au XXe siècle. Genève au coeur d'une utopie, edited by Rita Hofstetter, Joëlle Droux, Michel Christian. Geneva: Aphil, Presses Universitaires Suisse. Available at https://www.alphil.com/ freedownload.php?sku=978-2-88930-323-6. Accessed: 11 November 2020.

Lecuyer, Catherine. 2020. "La perspective montessorienne face au mouvement de léducation nouvelle dans la francophonie européenne du début du XXe siècle." European Review of History 27. https://www.tandfonline.com/doi/full/10.1080/13507486.2020.1765150 Accessed: 28 September 2021.

Ligue Internationale pour l'Éducation Nouvelle. 1922. "Principes de ralliement". Pour l'Ère nouvelle, 1, 2.

Ligt Van Rossem, Catherina. 1927. "Un témoignage hollandais en faveur de la méthode Montessori”. Pour l'Ẻre nouvelle, 29, 113-115.
Lombardo-Radice, Giuseppe. 1926. "Lécole active dans la réforme du Ministre Gentile”. Pour l'Ère nouvelle, 23, 176-184.

Marazzi, Giuliana. 2000. "Montessori e Mussolini : la collaborazione e la rottura". Dimensioni e problemi della ricerca storica, 1, 177-195.

Montessori, Maria. 1913. Il metodo della Pedagogia Scientifica, applicato alleducazione infantile nelle Case dei bambini. Seconda edizione accresciuta ed ampliata. Rome: Ermanno Loescher.

ND. 1922. "Notre ligue". Pour l'Ère nouvelle, 3, 49-50.

ND. 1923. "Notre ligue". Pour l'Ère nouvelle, 6, 21-23.

ND. 1923. "Notre ligue". Pour l'Ère nouvelle, 7, 43-45.

ND. 1927. "Chroniques du congrès". Pour l'Ëre nouvelle, 32, 262-268.

Pesci, Furio. 2019. "Montessori e la questione della pace." In Lutopia montessoriana. Pace, diritti, libertà, ambie$n e$, edited by Massimo Baldacci, Miguel A. Zabalza, 92-112. Rome: Erickson.

Philippi-Van Reesema, Cornelia. 1926. "Les précurseurs de Mme Montessori 1". Pour l'Ère nouvelle, 21, 82-85.

Philippi-Van Reesema, Cornelia. 1926. "Les précurseurs de Mme Montessori 3”. Pour l'Ëre nouvelle, 23, 171-175.

Philippi-Van Reesema, Cornelia. 1927. "Les écoles Montessori de La Haye”. Pour l'Ëre nouvelle, 32, 229-233.

Pironi, Tiziana. 2007. "La cure educative nelle scuola di Mompiano e nelle case dei bambini di Roma e di Milano età giolittiana." Pedagogia e Didattica dei Servizi Educativi 2: 27-39.

Pironi, Tiziana. 2018. "Maria Montessori e gli ambienti milanesi dell'Unione Femmiline e della Società Umanitaria." Annali di Storia dell'Educazione 25: 8-26.

Pozzi, Irene. 2015. "La Società Umanitaria e la diffusione del Metodo Montessori (1908-1923)." Ricerche di Pedagogia e Didattica - Journal of Theories and Research in Education, 10(2): 103-114.

Radice, Sheila. 1920. The New Children. Talks with Dr. Maria Montessori. New York: Frederic A. Stockes Company Publishers.

Roubiczek, Lili. 1927. "Les méthodes nouvelles- les tout petits". Pour l'Ère nouvelle, 32, 228-229.

Trabalzini, Paola. 2011. "Maria Montessori through the seasons of the 'Method"' The NAMTA Journal 36(2).

Wagnon, Sylvain. 2013. Ovide Decroly, un pédagogue de l'Éducation nouvelle (1871-1932). Bern: Peter Lang.

Wagnon, Sylvain. 2017. "Les théosophes et l'organisation internationale de l'Éducation nouvelle (1911-1921)." RHEMLAC 9(1): 146-180. 